FACTA UNIVERSITATIS

Series: Physical Education and Sport, Vol. 16, No 2, 2018, pp. 477 - 486

https://doi.org/10.22190/FUPES180606042M

Research article

\title{
GAME-RELATED STATISTICS THAT DISCRIMINATED WINNING AND LOSING TEAMS IN THE NLB LEAGUE
}

\author{
UDC 796.323:615.036
}

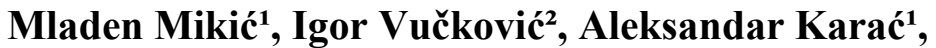 Bogdan Belegišanin'1, Veljko Vukićević1, Marko Stojanović́}

${ }^{1}$ University of Novi Sad, Faculty of Sport and Physical Education, Novi Sad, Serbia ${ }^{2}$ University of Banja Luka, Faculty of Sport and Physical Education, Banja Luka, Bosnia and Herzegovina

\begin{abstract}
The purposes of this study were (I) to examine which game-related statistics can serve to discriminate between winning and losing teams according to final game outcome in NLB League basketball, and (II) to determine the differences in game-related statistics for teams who play in the NLB League and EuroLeague when they win and lose in two competitions. The game-related statistics that were analyzed are 2- and 3-point fieldgoals (both successful and unsuccessful), free-throws (both successful and unsuccessful), defensive and offensive rebounds, assists, turnovers, steals, blocks made, blocks received, fouls committed and fouls received. Results of the discriminant analysis showed that winning teams differ from losing teams in assists $(S C=0.417)$, defensive rebounds $(S C=0.399)$ and in successful 2-point ( $S C=0.355)$ and 3-point field goals $(S C=0.325)$. In balanced games winning differ from losing teams in defensive rebounds $(S C=0.388)$, successful 2-point field goals (SC=0.343) and blocks committed $(S C=0.303)$, and in unbalanced games winners were better in assists $(S C=0.434)$, defensive rebounds ( $S C=0.304)$ and successful 3-point field goals (SC=0.353). When the teams Partizan, Olimpija and Cibona played in the NLB League, the difference between wins and losses was in assists (SC=0.395), successful 2-point field goal attempts $(S C=0.371)$ and defensive rebounds $(S C=0.326)$. When they played in the EuroLeague, the difference was only in unsuccessful 2-point field goal attempts $(S C=0.414)$ and blocks received (SC=0.318). Data obtained in this study may be useful for coaches in preparing their teams and analyzing opponents during preparations for competitions.
\end{abstract}

Key words: basketball, game-statistics, discriminant analysis, winners, losers

Received June 6, 2018 / Accepted September 17, 2018

Corresponding author: Mladen Mikić

University of Novi Sad, Faculty of Sport and Physical Education, Lovćenska 16, 21000 Novi Sad, Serbia

Phone: +38121 450188•E-mail: mmmikac@gmail.com 


\section{INTRODUCTION}

Basketball game-related statistics has become a widespread tool that coaches use to analyse their and opponent teams. Coaches use this tool to analyse individual contibutions to team performance, and team performance in comparison to the coaches' expectations before the game. Further, coaches use game-related statistics to analyse opponents as individuals and as a team. Analysis of basketball game-related statistics has also been used for the better understanding of the game, in particular the conribution of certain parameters to the quality of team performances.

Previous research analyzed game-related statistics from different club competitions: in NCAA (Akers, Wolff, \& Buttross, 1991), NBA League (Mikolajec, Maszczyk, Zajac, 2013; Melnick, 2001), WNBA (Gómez, Lorenzo, Ortega, Sampaio, \& Ibáñez, 2009), ACB League (García, Ibáñez, De Santos, Leite, \& Sampaio, 2013; Gómez, Lorenzo, Sampaio, Ibáñez, Ortega, 2008), Euroleague (Trninić, Dizdar, Luksić, 2002; Štrumbelj, Vračar, Robnik-Šikonja, Dežman, \& Erčulj, 2013), or from FIBA competitions of national teams (Ibáñez, García, Feu, Lorenzo, Sampaio, 2003; Lorenzo, Gómez, Ortega, Ibáñez, \& Sampaio, 2010; Karapidis, Fotinakis, Taxildaris, \& Fatouros, 2001; Ortega, Cárdenas, Sainz de Baranda, \& Palao, 2006; Sampaio, Ibáñez, \& Feu, 2004). Available research has shown that in basketball, winning teams differ in losing mostly in successful field-goal attempts (Akers, Wolff \& Buttross, 1991; García, Sáez, Ibáñez, Parejo, \& Cañadas, 2009; García et al., 2013;) and defensive rebounds (Akers, Wolff, \& Buttross, 1991; García et al., 2009; García et al., 2013; Gomez et al., 2009). In the NCAA, winning teams had a higher number of rebounds, higher percentages of 2-point shots, free-throw shots, and lower numbers of turnovers and steals (Akers, Wolff, \& Buttross, 1991). Melnick (2001) identified a positive correlation between team assists and the win-loss record. Gómez et al. (2009) showed that in the WNBA games the most powerful variables discriminating between starters and nonstarters are successful 2-point shots, successful freethrows and assists. When winning teams play home they differ from losing teams in defensive rebounds and assists. On the other hand, winning teams differ from losing teams when they play away in defensive rebounds, assists, successful 2-point field goals and unsuccessful 3-point field goals (Gomez et al., 2009). García et al. (2013) analyzed games from the Spanish Basketball League (ACB). In games from regular seasons, winning teams differ from losing teams in assists, defensive rebounds and successful 2 and 3-point field-goals. In playoff games, winning teams dominated only in defensive rebounding. In the analysis of games of final tournaments of European club championships from 1992 to 2000, Trninić et al. (2002) showed that winning teams dominated in the variable defensive rebounds, field goal percentage and free throw percentage. In a study from 2013, Mikolajec et al. analyzed advanced statistics and showed that most critical indicators of sports performance in the NBA are mostly offensive factors. Researchers have reported that $62 \%$ of the basketball games in the Brasil championship are won by home teams (De Rose, 2004). In the National Basketball Association (USA) home advantage has been examined and was levelled off at about 60\% (Pollard \& Pollard, 2005). Sampaio \& Janeira (2003) concluded that playoff games, due to game importance, have a lower number of ball possessions.

The NLB League (named due to sponsorship reasons) is commonly known as the Adriatic League. It is a regional professional league, basically composed of clubs from the former Yugoslavia. Three clubs from the NLB League in the 2007/2008 and 2008/2009 seasons played in Euroleague: Partizan, Olimpija and Cibona. During that period they played 96 games, 
winning 37 games and losing 59. At the same time, during the 2008/2009 season, those clubs played 82 games in the NLB League, winning 55 and losing 27 games.

\section{METHODS}

The sample was collected from all the games of the NLB League (a total of 185) from the 2008/2009 season, and games from the EuroLeage that 3 teams from the NLB League (Partizan, Cibona and Olimpija) played in two seasons - 2007/2008 and 2008/2009 - a total of 96 games. All of the games from the NLB League were divided into two groups based on the final score difference: those with a final score of 12 or fewer points (balanced) and a second group for games with a final score of more than a 12-point difference (unbalanced games).

A total of 251 games were analyzed with the following variables, selected according to the FIBA normative for game analysis: 2- and 3-point field goals (both successful and unsuccessful), free-throws (both successful and unsuccessful), defensive and offensive rebounds, assists, steals, turnovers, blocks (both made and received) and fouls (both committed and received). All the data were collected by experts from the Leagues. Ball possession was calculated as suggested by Oliver (2004) and Kubatko, Oliver, Pelton, \& Rosenbaum, (2007) by the following equations: Ball Possessions = (field-goals attempted) - (offensive rebounds) + (turnovers) - $0.4 \mathrm{x}$ (free-throws attempted). All the game-related statistics were normalized to 100 ball possessions in order to account for differences in game pace (Sampaio \& Janeira, 2003). Descriptive statistics, means and standard deviations were calculated. Univariate analysis of variance was used to compare the means of winning and losing teams.

In order to compare game-related statistics of winning and losing teams, a discriminant analysis was implemented. This analysis identifies the game-related statistics that best discriminate between winning and losing teams through structural coefficients. Structural coefficients $\geq 0.30$ were considered relevant (Tabachnick \& Fidell, 2001).

\section{RESULTS}

Table 1 shows the descriptive statistics results and univariate differences between winning and losing teams in the NLB League for all games, and separately for games that finish with a difference of 12 or fewer points (balanced) and games with a final score of more than 12 points (unbalanced). The results for all the games found significant differences between winning and losing teams in the following variables: winning teams had higher values in successful 2- and 3-point field goals, unsuccessful 3-point shots, defensive rebounds, assists, steals and committed blocks. Losing teams have more unsuccessful 3-point shots. In balanced games, winning teams have more successful field goal attempts (both 2 and 3-point), successful free-throws, offensive and defensive rebounds and blocks committed. Losing teams have more blocks and fouls received. In unbalanced games teams that win games was better in 6 variables: successful field goals (both 2 and 3 point), defensive rebounds, assists, steals and blocks committed. Losing teams have more unsuccessful 3-point shots and free-throws and blocks received. 
Table 1 Means, standard deviations, and univariate differences between winning and losing teams for all games, balanced and unbalanced games in the NLB League

\begin{tabular}{|c|c|c|c|c|c|c|}
\hline \multirow{2}{*}{ Game statistics } & \multicolumn{2}{|c|}{ All games } & \multicolumn{2}{|c|}{ Balanced games } & \multicolumn{2}{|c|}{ Unbalanced games } \\
\hline & Winners & & nners & Losers & Winners & \\
\hline It & 40.05 & 34.9 & & 35.70 & 40.72 & 8.6 \\
\hline & & 31.2 & & & & \\
\hline & & & & & & \\
\hline & 25.0 & 26.8 & & & & \\
\hline & 326 & 28.7 & & & 39 & \\
\hline & & & & & & \\
\hline & 45 & 71 & & & 42.0 & \\
\hline & & 15.7 & & & & 7.07 \\
\hline & 7.92 & 20.3 & 24 & 21.2 & 28.48 & \pm 6.73 \\
\hline & $14 \pm 6.31$ & 15.1 & & & 18.28 & \pm 6.61 \\
\hline & 6 & 26.3 & & 25.8 & 23.1 & \pm 6.61 \\
\hline & & & & & & \\
\hline & .38 & & & & 2.6 & \\
\hline & $.21 \pm 13.77$ & 1.10 & $.63 \pm 11.38$ & $.63=$ & $3.35 \pm 17.83$ & $40.78 \pm 9.05$ \\
\hline ouls received $\dagger$ & 3.44 & $42.52 \pm 12.35$ & $46.91 \pm 14.46$ & $42.63 \pm 12.85$ & $40.10 \pm 9.63$ & $42.28 \pm 11.34$ \\
\hline
\end{tabular}

$* p \leq 0.05$ in all games; $\uparrow \mathrm{p} \leq 0.05$ in balanced games; $\# \mathrm{p} \leq 0.05$ in unbalanced games.

Table 2 Discriminant Analysis Structure Coefficients (SC) between winning and losing teams for all games, balanced and unbalanced games from the NLB League

\begin{tabular}{|c|c|c|c|}
\hline Game statistics & All games & Balanced games & Unbalanced games \\
\hline Assists *\# & .417 & .295 & .434 \\
\hline Defensive rebounds $* \uparrow \#$ & .399 & .388 & .304 \\
\hline Successful $2 p^{* \dagger}$ & .355 & .343 & .271 \\
\hline Successful 3p *\# & .325 & .229 & .353 \\
\hline Blocks made $\dagger$ & .277 & .303 & .194 \\
\hline Blocks received & -.229 & -.209 & -.207 \\
\hline Steals & .179 & .120 & .188 \\
\hline Successful FT & .169 & .244 & .046 \\
\hline Turnovers & -.167 & -.090 & -.199 \\
\hline Unsuccessful $3 p$ & -.119 & -.021 & -.188 \\
\hline Offensive rebounds & .099 & .174 & -.006 \\
\hline Fouls received & .097 & .214 & -.066 \\
\hline Unsuccessful 2p & -.080 & .012 & -.137 \\
\hline Fouls committed & .039 & .000 & .058 \\
\hline Unsuccessful FT & -.005 & .114 & -.139 \\
\hline Wilks Lambda & .568 & .651 & .287 \\
\hline Canonical Correlation & .657 & .591 & .844 \\
\hline Chi-squared & 203.742 & 102.984 & 138.561 \\
\hline Significance & .000 & .000 & .000 \\
\hline Reclassification & $82.9 \%$ & $79.9 \%$ & $96.7 \%$ \\
\hline
\end{tabular}


The minus sign in the structure coefficients means that losing team's performance was higher than the winning team's performance. The results of the discriminant analysis (Table 2.) showed that winning teams differ from losing teams in assists $(\mathrm{SC}=0.417)$, defensive rebounds $(\mathrm{SC}=0.399)$ and in successful field goals for 2-points $(\mathrm{SC}=0.355)$ and 3 -points $(\mathrm{SC}=0.325)$. In balanced games winning differ from losing teams in defensive rebounds ( $\mathrm{SC}=0.388)$, successful 2-point shots $(\mathrm{SC}=0.343)$ and blocks committed $(\mathrm{SC}=0.303)$, and in unbalanced games winners was better in assists $(\mathrm{SC}=0.434)$, defensive rebounds $(\mathrm{SC}=0.304)$ and successful 3-point shots $(\mathrm{SC}=0.353)$. This analysis correctly classified $84.7 \%$ of the data from all games, $79.9 \%$ for balanced games and $96.7 \%$ of the data from unbalanced games.

When the teams Partizan, Cibona and Olimpija (teams that play both in the NLB and EuroLeague) play in the NLB League, a statistically significant difference between win and loss was in successful field goal attempts (both for 2 and 3-point), rebounds (defensive and offensive), assists, blocks committed and fouls received. On the other hand, when they play in the EuroLeague, the statistically significant difference between win and loss was noted in successful 3-point shots, assists, unsuccessful 2-point shots and blocks received (Table 3 .).

Table 3 Means, standard deviations, and univariate differences from game performance indicators by winning and losing games for 3 teams when they play NLB League and EuroLeague

\begin{tabular}{lcccc}
\hline Game statistics & \multicolumn{2}{c}{ NLB } & \multicolumn{2}{c}{ EuroLeague } \\
\cline { 2 - 5 } & Winning & Losing & Winning & Losing \\
\hline Successful 2p * & $43.35 \pm 8.38$ & $39.73 \pm 8.46$ & $32.56 \pm 17.04$ & $30.43 \pm 13.12$ \\
Unsuccessful 2p $\ddagger$ & $32.22 \pm 9.24$ & $32.58 \pm 9.34$ & $31.03 \pm 8.98$ & $38.37 \pm 8.42$ \\
Successful 3p * $\ddagger$ & $14.92 \pm 4.76$ & $11.57 \pm 4.74$ & $15.57 \pm 5.66$ & $12.38 \pm 5.14$ \\
Unsuccessful 3p & $40.33 \pm 22.70$ & $41.27 \pm 23.70$ & $26.60 \pm 7.95$ & $27.1922 \pm 8.50$ \\
Successful FT & $35.38 \pm 20.19$ & $30.65 \pm 14.86$ & $32.80 \pm 15.97$ & $27.82 \pm 15.12$ \\
Unsuccessful FT & $11.77 \pm 7.69$ & 10.165 .33 & $9.9732 \pm 5.6648$ & $10.43 \pm 7.08$ \\
Defensive rebounds * & $46.38 \pm 13.36$ & $38.97 \pm 8.58$ & $46.55 \pm 10.65$ & $41.94 \pm 12.63$ \\
Offensive rebounds * & $18.68 \pm 7.85$ & $15.31 \pm 7.31$ & $20.00 \pm 9.10$ & $20.90 \pm 9.18$ \\
Assists * $\ddagger$ & $26.80 \pm 8.36$ & $20.85 \pm 7.02$ & $24.77 \pm 8.31$ & $20.3312 \pm 6.73$ \\
Steals & $17.65 \pm 6.28$ & $15.93 \pm 4.71$ & $9.87 \pm 4.80$ & $10.09 \pm 4.99$ \\
Turnovers & $27.66 \pm 8.35$ & $27.92 \pm 7.93$ & $29.24 \pm 9.19$ & $32.16 \pm 9.21$ \\
Blocks made * & $7.59 \pm 5.39$ & $5.34 \pm 3.78$ & $5.87 \pm 4.00$ & $4.68 \pm 3.80$ \\
Blocks received $\ddagger$ & $3.5112 \pm 3.29$ & $4.38 \pm 3.80$ & $3.73 \pm 3.30$ & $5.97 \pm 3.53$ \\
Fouls committed & $46.56 \pm 12.74$ & $47.43 \pm 10.33$ & $47.05 \pm 11.61$ & $48.727 \pm 10.94$ \\
Fouls received * & $46.37 \pm 16.19$ & $41.20 \pm 11.98$ & $43.56 \pm 13.00$ & $40.49 \pm 13.45$ \\
\hline
\end{tabular}

$* \mathrm{p} \leq 0.05$ in NLB games; $\$ p \leq 0.05$ in EuroLeague games. 
Table 4 Discriminant Analysis Structure Coefficients (SC) from game performance indicators by wins and losses for 3 teams when they play in the NLB League and EuroLeague

\begin{tabular}{lcc}
\hline Game statistics & NLB & EuroLeague \\
\hline Assists * & .395 & -.292 \\
Successful 3p * & .371 & -.290 \\
Defensive rebounds * & .326 & -.189 \\
Blocks made & .241 & -.150 \\
Offensive rebounds & .231 & .048 \\
Successful 2p & .227 & -.070 \\
Fouls received & .182 & -.113 \\
Steals & .157 & .022 \\
Successful FT & .134 & -.157 \\
Blocks received $\$$ & -.132 & .318 \\
Unsuccessful FT & .121 & .034 \\
Fouls committed & -.038 & .073 \\
Unsuccessful 3p & -.021 & .035 \\
Unsuccessful 2p $\ddagger$ & -.021 & .414 \\
Turnovers & -.016 & .155 \\
Wilks Lambda & .550 & .491 \\
Canonical Correlation & .671 & .714 \\
Chi-squared & 91.739 & 58.045 \\
Significance & .000 & .000 \\
Reclassification & $84.7 \%$ & $83.5 \%$ \\
\hline SC $\geq .30$ in NLB games; $\$$ SC $\geq .30$ in EuroLeague games.
\end{tabular}

The results of the discriminant analysis (Table 4.) showed that when these three teams played in the NLB League, the difference between wins and losses was in assists ( $\mathrm{SC}=0.395)$, successful 2-point field goal attempts $(\mathrm{SC}=0.371)$ and defensive rebounds $(\mathrm{SC}=0.326)$, but when they played in the EuroLeague, the difference was only in unsuccessful 2-point field goal attempts $(\mathrm{SC}=0.414)$ and blocks received $(\mathrm{SC}=0.318)$. This analysis correctly classified $84.7 \%$ of the data from the NLB League and $83.5 \%$ of the data from the EuroLeague.

\section{DISCUSSION}

The purpose of the present study was to identify the basketball game-related statistics that best discriminate winning and losing teams in the NLB League according to final game outcome, and to determine the differences in game-related statistics for teams who play in the NLB League and EuroLeague when they win and lose in two competitions (Partizan, Olimpija and Cibona). Winning teams in the NLB League play a better defense, expressed through steals and blocks made, while not allowing the opponent team to play in the way they trained, forcing them to shoot from bad positions. Also, winning teams provide a space near the basket to rebound after a player from the offense team attempts a field-goal shot. In offense, the winning teams play till they reach good positions for the shot, with the cooperation of several players, which is shown through assistances and successful field-goal shots. 
Defensive rebounds were the only game statistic that discriminates between winning teams and losing teams in all three analyses (all games, balanced or unbalanced). Several previous studies confirm their importance, regardless of the level of competition or the sex of the players (Sampaio \& Janeira, 2003; Ibáñez et al., 2003; Gómez et al., 2008; García et al., 2013). Defensive rebounds are indicators of good team defense. The goal of good defense is to prevent offensive players from shooting freely without defense, and from the position where they are shooting at a high percentage, and then to box out and prevent offensive players from taking the ball. This increases the number of unsuccessful shots and the chance for a defensive rebound. Teams that have more rebounds in defense have more chances for fastbreaks, so offense must take care to defend the fastbreaks and fewer players go for rebound in offense. Better individual and team defensive pressure (teamwork) forces offensive players to take bad shots, from bad positions, with a lower success and in a weaker position for an offensive rebound.

For all games, assists were the most powerful variable discriminating between winning and losing teams, which is in accordance with some previous studies (Melnick, 2001; García et al., 2013; Gómez et al., 2008; Ibáñez et al., 2009). The variable assists is the only game-related variable that must be the product of cooperation between at least two players. According to the FIBA normative, a good pass counts as an assist only if it is followed by a successful field-goal attempt. Usually it is the product of teamwork, good organized and the well-trained play of a team, with the goal that a player shoots from where he shoots with a high percentage of success (Gómez et al., 2008). Two remaining variables that discriminate between winning and losing teams in all games are variables of successful field-goal attempts (2- and 3-point field-goal attempts). Successful shooting can be the effect of better individual player techniques and tactics, higher quality of players, along with better trained teamwork. Several studies (Lorenzo et al., 2010; Trninić et al., 2002; García et al., 2013) confirm that successful field-goal attempts are the most powerful variables in discriminating between winning and losing teams. Winning teams have more successful field-goal attempts and a lower number of unsuccessful field-goal shots. It is a consequence of better organized team play, players well trained to recognize when and where from to attempt to score. Individual player quality is reflected in decision-making on the court, during the game, making the right decisions based on the situation in the game.

For balanced games, after defensive rebounds, successful 2-point field-goal attempts is the next most powerful variable that discriminates between winning and losing teams (Trninić et al., 2002; García et al., 2013). In previous studies (Ortega et al., 2006; Lorenzo et al., 2010; Akers et al., 1991) variable successful 2-point shots were characterized as most powerful in discriminating between successful and unsuccessful teams. Teams that play good defense and have more defensive rebounds have more opportunities to play fastbreaks and to finish offense from an area under the basket, shooting with a high percentage (Gomez et al., 2008; Ibáñez et al., 2008). Blocks made are the effect of better quality of defenders (technically and physically), and better defensive pressure that forces the opponent to shoot from a bad position (García et al., 2009).

In unbalanced games, the variable assists has discriminating power, as do defensive rebounds and successful 3-point field-goals. Teams that dominate during the game have more defensive rebounds as a result of better team defensive pressure and lower level of individual techniques of offensive players. Assists are the product of good teamwork, 
better offensive plays (coach role) and a higher quality of players. In unbalanced games, with final game outcomes of 12 or more points, the variable of the 3-point field goal distinguishes between winning and losing teams in unbalanced games (Ibáñez et al., 2009; Karapidis et al., 2001).

The second goal of this study was to analyze game-related statisticsof three teams that played in the NLB League and EuroLeague (Partizan, Olimpija and Cibona). In the NLB League games, the difference between win and loss was in variables assists, successful 3point field goals and defensive rebounds. The variables assists and defensive rebounds are the most powerful variable that distinguish between winning and losing teams in many previous studies (García et al., 2013; Gómez et al., 2008; Ibáñez et al., 2009). The variable successful 3-point field goal is probably the effect of the difference in the quality of teams as can be seen in win/loss relation: 82 games, 55 wins and 27 losses. In the EuroLeague, these teams played 96 games, winning 37 games and losing 59 games. In these games, unsuccessful 2-point shots and blocks received are variables that best indicate the difference between a win and loss. When these 3 teams from the NLB play a higher level of competition (EuroLeague) it seems that they play against teams that have better individual players who play better defense, both individual and team. Opponents force teams from the NLB League to shoot from bad positions, when the defense is close and the tall players are ready to stop the shot towards the basket. Higher level of competition, and better quality of opponent players and teams can be possible explanations for these results.

\section{CONCLUSION}

The results were consistent with previous studies (Trninić et al., 2002; García et al., 2013; Gómez et al., 2008) and pointed out the importance of team preparation for defensive pressure that forces offensive players to take bad shots, and protect the area under the basket. Offensive team play indicated by the number of assists provides open shots from good positions and with a high percentage of success (García et al., 2013; Gómez et al., 2008). Defensive rebounds were the only game statistic that discriminated between winning and losing teams in all performed analyses (all games, balanced and unbalanced). When three teams played in the EuroLeague, the difference in unsuccessful 2-point field goal attempts and blocks received is probably due to higher quality of opponent players and teams. The win/loss relation shows that the teams from the NLB League had a lower level of player and team qualities compared to the other teams that participated in the EuroLeague. Data obtained in this study may be useful for coaches in preparing their teams and analyzing opponents during preparations for competitions.

\section{REFERENCES}

Akers M., Wolff S., \& Buttross T. (1991). An empirical examination of the factors affecting the success of NCAA Division I college basketball teams. The Journal of Business and Economic Studies, 1, 57-71

De Rose, D.J. (2004). Statistical analysis of basketball performance indicators according to home/away games and winning and losing teams. Journal of Human Movement Studies, 47, 327-336.

García, J., Sáez, J., Ibáñez, S.J., Parejo, I., \& Cañadas, M. (2009). Home advantage analysis in ACB League in season 2007-2008. Revista de Psicologia del Deporte, 18, 331-335. 
García, J., Ibáñez, S.J., De Santos, R.M., Leite, N., \& Sampaio, J. (2013). Identifying Basketball Performance Indicators in Regular Season and Playoff Games. Journal of Human Kinetics, 36, 161-168.

Gómez, M.A., Lorenzo, A,, Sampaio, J., Ibáñez, S.J., Ortega, E. (2008). Game-related statistics that discriminated winning and losing teams from the Spanish men's professional basketball teams. Collegium Antropologicum, 32(2), 315-319.

Gómez, M.A., Lorenzo, A., Ortega, E., Sampaio, J., \& Ibáñez, S.J. (2009). Game related statistics discriminating between starters and nonstarters players in Women's National Basketball Association League (WNBA). Journal of Sports Science and Medicine, 8: 278-283.

Ibanez, S. J., Sampaio, J., Saenz-Lopez, P., Gimenez, J., \&Janeira, M. A. (2003). Game statistics discriminating the final outcome of Junior World Basketball Championship matches (Portugal 1999). Journal of Human Movement Studies, 45, 1-19.

Ibáñez, S.J., García, J., Feu, S., Lorenzo, A., Sampaio, J. (2009). Effect of consecutive basketball games on the game-related statistics that discriminate winner and losing teams. Journal of Sports Science and Medicine, 8: 458-462.

Karapidis, A., Fotinakis, A., Taxildaris, K. \& Fatouros, J. (2001). Factors characterizing a successful performance in basketball. Journal of Human Movement Studies, 14, 5: 385-398.

Lorenzo, A., Gómez, M.A., Ortega, E., Ibáñez, S.J. \& Sampaio, J. (2010) Game related statistics which discriminate between winning and losing under-16 male basketball games. Journal of Sports Science and Medicine, 9: 664-668.

Mikolajec, K., Maszczyk, A., Zajac, T. (2013). Game Indicators Determining Sports Performance in the NBA. Journal of Human Kinetics, 37: 145-151.

Melnick, M.J. (2001). Relationship between team assists and win-loss record in the National Basketball Association. Perceptual and Motor Skills, 92(2), 595-602.

Kubatko, J., Oliver, D., Pelton, K., \& Rosenbaum, D. (2007). A starting point for analyzing basketball statistics. Journal of Quantitative Analysis in Sports, 3, 1-22.

Oliver, D. (2004). Basketball on paper: Rules and tools for performance analysis. Washington, DC.Brassey's, Inc. Pollard and Pollard.

Ortega, E., Cárdenas, D., Sainz de Baranda, P., \& Palao, J.M. (2006). Differences Between Winning and Losing Teams in Youth Basketball Games (14-16 Years Old). International Journal of Applied Sports Sciences, 18, 2, 1-11.

Pollard, R. \& Pollard, G. (2005). Long-term trends in home advantage in professional team sports in North America and England (1876 - 2003). Journal of Sports Sciences, 23, 4, 337-350.

Sampaio, J., \& Janeira, M. (2003). Statistical analyses of basketball team performance: Understanding teams' wins and losses according to a different index of ball possessions. International Journal of Performance Analysis in Sport, 3, 40-49.

Sampaio, J., Ibáñez, S. J., \& Feu, S. (2004). Discriminative power of basketball game-related statistics by level of competition and sex. Perceptual and Motor Skills, 32, $1231-1238$.

Štrumbelj, E., Vračar, P., Robnik-Šikonja, M., Dežman, B. \& Erčulj, F. (2013). A Decade of Euroleague Basketball: an Analysis of Trends and Recent Rule Change Effects. Journal of Human Kinetics, 38, 183-189.

Trninić S, Dizdar D, Luksić E. (2002). Differences between winning and defeated top quality basketball teams in final tournaments of European club championship. Collegium Antropologicum, 26(2): 521-531.

Tabachnick B. \& Fidell L. (2001). Using multivariate statistics. (4th ed.). New York: Harper \& Row Publ.

\section{VARIJABLE ZVANIČNE STATISTIKE KOJE RAZDVAJAJU POBEDNIČKE I PORAŽENE EKIPE U UTAKMICAMA NLB LIGE}

Cilj ovog istraživanja je (I) da se utvrdi koje varijable zvanične statistike značajno razdvajaju pobedničke i poražene timove u utakmicama košarkaške NLB Lige, i (II) da odredi razlike u zvaničnoj statistici za timove koji igraju i NLB Ligu i Evroligu kada pobeđuju i gube u dva takmičenja. Utakmice $N L B$ Lige su razdvojene prema razlici u konačnom rezultatu: na utakmice sa krajnjom razlikom $12 i$ manje poena (uravnotežene) $i$ utakmice sa krajnjom razlikom većom od 12 poena (neuravnotežene). Rezultati diskriminativne analize svih utakmica NLB Lige su pokazali da se pobedničke ekipe rezlikuju od poraženih ekipa u varijablama asistencije $(S C=0.417)$, skok u odbrani $(S C=0.399)$ i uspešni šutevi za 2 poena (SC=0.355) i 3 poena (SC=0.325). U uravnoteženim utakmicama pobedničke ekipe se od 
486 M. MIKIĆ, I. VUČKOVIĆ, A. KARAĆ, B. BELEGIŠANIN, V. VUKIĆEVIĆ, M. STOJANOVIĆ

poraženih ekipa razlikuju u varijablama skok u odbrani ( $S C=0.388)$, uspešan šut za 2 poena $(S C=0.343)$ $i$ načinjene blokade ( $S C=0.303)$, dok je u neuravnoteženim utakmicama značajna razlika u varijablama asistencija ( $S C=0.434)$ skok u odbrani $(S C=0.304)$ i uspešan šut za 3 poena $(S C=0.353)$. Kada su ekipe Partizan, Olimpija i Cibona igrale utakmice NLB Lige razlika između pobede i poraza je u varijablama asistencija ( $S C=0.395)$, uspešan šut za 2 poena $(S C=0.371)$ i skok u odbrani $(S C=0.326)$. Kada su ovi timovi igrali Evroligu razlika u zvaničnoj statistici između pobede i poraza je u varijablama neuspešan šut za 2 poena ( $S C=0.414)$ i primljene blokade $(S C=0.318)$.

Ključne reči: košarka, zvanična statistika, diskriminativna analiza, pobednici, poraženi 